\title{
BOOMSMA OOR DIE CRC IN DIE VSA.
}

In die Calvin Theological Journal van April 1984 (19(1): 32-49) het 'n interessante artikel van die hand van ds. Clarence Boomsma verskyn onder dio titel Whot has hoippened Theologically to the Christian Reformed Church since World War II? Omdat die GKSA in geloofsgemeenskap (enger korrespondensie) met die CRC leef, is dit wenslik om na enkele hooftrekke in die voordrag van ds. Boomsma te kyk.

Sy voordrag bestaan uit drie dele: eerstens konstateer hy 'n nog besondere eenheid in die CRC; tweedens verwys hy na sy waarnemings ivm die teo'ogiese ontwikkelinge in die CRC en derdens sluit hy af met persoonlike kommentar.

Hy begin deur te verwys na die doktorsproefskrif van John Kromminga oor die CRC, met as subtitel "A Study in Orthodoxy" (1949). Daarin verwys Kromminga na sewe oorweginge waarom die CRC as 'n ortodokse Calvinistiese kerk bekend staan. Sedertdien het baie winde van verandering ook teen die CRC aangewaai, meen ds. Boomsma, maar tog het die CRC "a remarkable degree of homogeneity and loyalty" bewaar. "Two factors contributed to our continuing religious and social cohesiveness: the strong ties of denominational bonds forged by the meaningful role of the faith as activity embodied in the church, and the widespread system of Christian education from grade schools to our fine colleges" (36).

Hierna beantwoord Boomsma die vraag oor die teologiese ontwikkeling in die CRC. Hy mak hier drie waarnemings.

Eerstens meen hy het die CRC teologies ortodoks gebly het. Hiertoe het cnkele faktore bygedra.

Tweedens het die CRC teologies gereformeerd gebly. Maar, "at the same time I want to observe that our Reformed character and commitnent is per- 
haps not held with the same vigorous loyalty, nor championed with the same passion, nor emphasized so acutely in the whole range of church teaching as was true forty years ago. This slippage began to be noticed and exhibited in certain theological tensions of the 1950's" (39).

In hierdie tyd het dr. Henry Stob 'n studie van die CRC onderneem en drie strominge of gedagterigtings ontdek: daar was diegene met 'n "mind of safety" wat isolasie beklemtoon het; daar was die "militant mind" (Torch and Trumpet) wat die geringste afwyking wou aanvat; en daar was die "positive mind" (The Reformed Journal) wat, hoewel gewortel in die reformatoriese erfenis, tog oop was "to change and growth in theological understanding". Nietieenstaande hierdie verskillende aksente is daar offisieel kerklik nie wegbeweeg van die reformatoriese erfenis nie (vgl. die beswaarskrif van Harry Boer). Tog bespeur Boomsma 'n afname in belangstelling en bespreking van konfessionele sake.

Sy derde waarneming is dat "theology no longer functions as the integrating center of the life and practice of the Christian Reformed Church" (43). Gemeentelike uniformiteit bestaan nie meer nie. "Preaching, liturgies, music, and interests differ considerably from church to church" (44). Boomsma vergelyk dit met ' $n$ wiel sonder naaf waarvan die speke in alle windrigtings wys. Klaarblyklik voel hy dit as 'n terugslag dat die "direction of the church is no longer . . . guided, corrected, and determined by its theology" - gelukkig defineer hy teologie dan as "a serious concern to understand and interpret the Word of God in conformity with our accepted creedal standards" (45).

Boomsma sluit af met vier opmerkings.

Eerstens, "we must choose what kind of church we believe we ought to be" (45). Boomsma self kies daarvoor dat die reformatoriese erfenis bewaar word.

Tweedens, "we must seriously consider revitalizing theological concern and discussion" (46).

Derdens, "we must allow for theological growth and exploration, for openness ..." (48). Boomsma meen dat daar enersyds opnuut gekyk moet word na die ondertekeningsformulier sodat die konfessionele kerkkarakter behou kan bly maar dat andersyds ruimte geskep word vir voortgaande Skriftuurlike reformasie.

Vierdens merk hy op dat die toekoms onvoorspelbaar is -

Sonder om breedvoerig op hierdie voordrag kommentaar te lewer, wil ek slegs twee opmerkings maak.

Ten eerste dat dit betwyfel kan word of 'n bepaalde teologie, hoe belangrik en hoe breed gedefinieer ook al, eenheid in kerke kan waarborg. Ek meen dat dit die funksie van die belydenisskrifte is wat juis formuliere van énheid is. Vir middelmatige sake moet daar uiteraard ruimte en vryheid wees (KO art. 85).

Ten tweede is opvallend hoe onkrities Boomsma se kerkbegrip is. Die CRC word sommer maklik "denominasie" genoem (45), ja 'n "small segment" van die liggaam van Christus (49), terwyl onproblematies verwys word na "the Canadian segment of our church" (41) Moet daar nie juis op hierdie punt met reformasie begin word nie? 